\title{
BUDŻET PARTYCYPACYJNY - WIEDZA I AKTYWNOŚĆ PRZEDSTAWICIELI POKOLENIA X
}

\begin{abstract}
Budżet partycypacyjny stanowi narzędzie zarządzania budżetem jednostki samorządowej wykorzystywane na świecie od prawie trzydziestu lat. Jego stosowanie daje członkom lokalnej społeczności możliwość współdecydowania o sposobie podziału całości lub części dostępnych środków publicznych. Wpływa między innymi na wzrost aktywności obywateli, przełamanie barier występujących pomiędzy władzą a mieszkańcami, realizacje istotnych dla lokalnych społeczności projektów. Pozytywne efekty, jakie dało wykorzystanie tej idei przez samorządy południowoamerykańskich miast stało się impulsem do jej stosowania przez władze samorządowe na wszystkich kontynentach. Aktualnie jest ona realizowana przez władze samorządowe ok. 3000 jednostek. Również polskie samorządy od $2011 \mathrm{r}$. wykorzystują ją w praktyce. Od tego czasu z roku na rok zwiększa się liczba polskich samorządów ją stosujących. Można nawet stwierdzić, że w Polsce pojawiło się coś w rodzaju ,mody" na budżet obywatelski.

W artykule zaprezentowano wyniki badań ankietowych dotyczących poziomu znajomości zagadnień związanych $\mathrm{z}$ budżetem partycypacyjnym przez przedstawicieli pokolenia $\mathrm{X}$, którzy na potrzeby przeprowadzonych badań zostali podzieleni na dwa segmenty wiekowe, będących mieszkańcami miasta Rzeszowa oraz stanu ich aktywności w tym zakresie. Na wstępie zaprezentowano ocenę stanu znajomości idei budżetu partycypacyjnego oraz poziomu wiedzy mieszkańców na temat procedur wykorzystywanych przy realizacji tej idei. W dalszej części dokonano oceny aktywności mieszkańców w zakresie budżetu partycypacyjnego oraz przeanalizowano czynniki wpływające na tą aktywność.
\end{abstract}

Słowa kluczowe: budżet partycypacyjny, demokracja uczestnicząca, opinie społeczne, pokolenie $\mathrm{X}$

\section{WPROWADZENIE}

Władze polskich samorządów poszukując metod pozwalających na wykorzystanie w optymalny sposób środków finansowych pozostających w ich dyspozycji zwróciły uwagę na opracowaną trzy dekady temu w Brazylii ideę budżetu partycypacyjnego ${ }^{2}$.

${ }^{1}$ Dr inż. Mirosław Sołtysiak, Zakład Finansów, Bankowości i Rachunkowości, Wydział Zarządzania, Politechnika Rzeszowska; e-mail: miroslaw@prz.edu.pl

2 Szerzej zob. B. Wampler, A guide to participatory budgeting. 2000. http://www.internationalbudget.org/wp-content/uploads/A-Guide-to-Participatory-Budgets.pdf (dostęp: 31.05.2016 r.); B. Wampler, Participatory Budgeting in Brazil. Contestation, Cooperation, and Accountability. The Pennsylvania State University Press, University Park, Pennsylvania 2007; N. Dias (org), Hope for Democrary 25 Years of Participatory Budgeting Worldwide. IN LOCO ASSOCIATION SÃO BRÁS DE ALPORTEL 2014. 
Budżet partycypacyjny jest definiowany jako narzędzie zarządzania budżetem jednostki samorządowej przy pomocy którego członkowie lokalnej społeczności mogą decydować lub przyczyniać się do podejmowania decyzji dotyczących sposobu podziału całości lub części dostępnych środków publicznych ${ }^{3}$. Metoda ta stanowi formę demokracji uczestniczącej i doskonale wpisuje się w ideę samorządności. Jest ona formą zwrócenia uwagi władz samorządowych na inicjatywy oraz opinie zgłaszane przez mieszkańców. Pozwala ona na przełamanie barier występujących pomiędzy mieszkańcami i władzą oraz zwiększenie zainteresowania lokalnych społeczności sprawami publicznymi ${ }^{4}$. Realizuje również cele edukacyjne związane z budowaniem społeczeństwa obywatelskiego.

Przy jej realizacji należy zwrócić uwagę, na to, by w trakcie procesu budżetowania partycypacyjnego zostały zachowane następujące elementy ${ }^{5}$ :

- ścisłe określenie wysokości środków, jakie zostały wyodrębnione na ten cel,

- umożliwienie udziału w pracach związanych z budżetem partycypacyjnym wszystkim mieszkańcom,

- honorowanie przez władze decyzji podjętej przez mieszkańców,

- założenie, że nie jest to działanie jednorazowe, tylko proces długofalowy.

Osiągnięcie sukcesu w realizacji budżetu partycypacyjnego jest więc wypadkową wielu zmiennych. Należy pamiętać, że budżet partycypacyjny to nie tylko efektywnie wykorzystane środki publiczne na priorytetowe dla lokalnej społeczności inwestycje mające na celu poprawę poziomu życia obywateli, ale również działania mające na celu zwiększenie aktywności mieszkańców w życiu społecznym. A przez to stworzenie więzi w lokalnej społeczności oraz wzrostu poziomu odpowiedzialności mieszkańców za wspólne dobro. Nie powinien on być realizowany jako kolejna „modna atrakcja dla mieszkańców", ale należy go wprowadzać w życie przy czynnym współudziale i zaangażowaniu obywateli. To mieszkańcy a nie radni czy pracownicy jednostki samorządowej powinni zgłaszać projekty zadań do budżetu partycypacyjnego ${ }^{6}$. Z założenia ma on bowiem pozwolić obywatelom niebędącym członkami władz samorządowych na wskazanie, jakie są ich oczekiwania co do wykorzystania środków finansowych jednostki samorządowej ${ }^{7}$. Nie powinien on również być nadużywany jako narzędzie walki politycznej, które

372 Frequently Asked Questions about Participatory Budgeting, Quito 2004.

${ }^{4}$ Szerzej zob. A. Shah (ed.), Participatory Budgeting, Washington 2007, s. 8.

5 Por. Y. Sintomer, A. Röcke, C. Herzberg, Participatory Budgeting in Europe: Potentials and Challenge, "International Journal of Urban and Regional Research" 2008, Vol. 32, No. 1.

6 Takie działanie radnych lub pracowników jednostek samorządowych może wynikać z obawy, że realizacja budżetu partycypacyjnego może wpłynąć na ograniczenie ich kompetencji w procesie zarządzania finansami jednostki samorządowej. Lęku, że budżet partycypacyjny może stać się narzędziem, przy pomocy którego mieszkańcy będą posiadać możliwość kontrolowania działań podejmowanych przez władze samorządowe.

Natomiast J. Lerner uważa, że pracownicy jednostek samorządowych powinni pełnić rolę nauczycieli w zakresie procedur budżetu partycypacyjnego a na mieszkańcach powinna spoczywać odpowiedzialność za podejmowanie decyzji o sposobie wydatkowania wydzielonej części budżetu. Szerzej zob. J. Lerner, Participatory Budgeting Building Community Agreement Around Tough Budget Decisions, "National Civic Review" 2011, Vol. 100, Issue 2.

7 Zob. szerzej Participatory Budgeting Worldwide - Updated Version. Dialog Global 25, Bonn 2013, s. 10. 
jest wykorzystywane w czasach zbliżających się kampanii wyborczych ${ }^{8}$. Działania takie mogą bowiem zniechęcić znaczną część społeczeństwa do udziału w nim. Z podobną sytuacją mamy do czynienia, gdy proces budżetowania partycypacyjnego zostanie narażony na ryzyko braku możliwości realizacji. Może być ono wynikiem dopuszczenia do niego zadania, które zgodnie z prawem nie może zostać zrealizowane ${ }^{9}$. A przez to aktywność obywateli, którzy poświęcili swój czas na włączenie do listy realizowanych projektów takiego zadania zostanie zmarnowana.

Dlatego, aby osiągnąć sukces w realizacji budżetu partycypacyjnego władze samorządowe muszą przekonać mieszkańców, że ich aktywność oraz chęć zaangażowania się w pracach mających na celu realizację wspólnego dobra nie zostanie zmarnowana w wyniku błędów proceduralnych, niedostosowania wielkości środków niezbędnych na realizację przyjętych zadań, a przede wszystkim poprzez niehonorowanie decyzji podjętych przez obywateli. Należy bowiem pamiętać, że realizacja idei budżetu partycypacyjnego ma szanse osiągnąć sukces jedynie wtedy, gdy mieszkańcy zechcą na każdym etapie jej realizacji masowo w niej uczestniczyć.

\section{METODYKA I CEL BADAŃ}

Budżet partycypacyjny jest nowym zjawiskiem związanym z polskimi finansami publicznymi ${ }^{10}$. W związku z tym brakuje prezentacji wyników kompleksowych badań naukowych prowadzonych w Polsce dotyczących tych zagadnień. Można jedynie odnaleźć informacje o badaniach przeprowadzonych przez niektóre samorządy po wdrożeniu w nich idei budżetu partycypacyjnego. Badania te jednak są nieporównywalne, gdyż zazwyczaj przeprowadzone zostały w ograniczonym zakresie w celu poznania jedynie opinii lokalnej społeczności na temat formy przeprowadzanego głosowania nad budżetem partycypacyjnym. Dodatkowo w większości przypadków zostały przeprowadzona na niewielkiej niereprezentatywnej grupie respondentów. Przykładami takich badań są badania ankietowe przeprowadzone m.in. przez miasta: Elbląg ${ }^{11}$, Kórnik ${ }^{12}$, Lublin ${ }^{13}$, Mysłowice ${ }^{14}$,

\footnotetext{
${ }^{8}$ Doświadczenia brazylijskie wskazują, że wprowadzenie budżetu partycypacyjnego zwiększa prawdopodobieństwo zwycięstwa w kolejnych wyborach burmistrza/prezydenta i jego partii o 10-15\%. Szerzej zob. P. Spada, The Economic and Political Effects of Participatory Budgeting. Prepared for delivery at the 2009 Congress of the Latin American Studies Association, Rio de Janeiro, Brazil June 11-14, 2009, s. 3, 18, http://citeseerx.ist.psu.edu/viewdoc/download?doi= 10.1.1.505.2726\&rep=rep1\&type $=$ pdf

9 Dla przykładu taka sytuacja miała miejsce w 2014 r. przypadku budżetu partycypacyjnego Kraśnika gdzie zostało przyjęte do realizacji zadanie niezgodne z ustawowymi zadaniami własnymi jednostki samorządowej. Po interwencji Regionalnej Izby Obrachunkowej zadanie to zostało zastąpione innym. Zob. www.dziennikwschodni.pl/krasnik/dach-kosciola-z-pieniedzymiasta-rio-tak-nie-mozna,n, 140419851.html

${ }^{10}$ Po raz pierwszy w praktyce $\mathrm{z}$ idei budżetu partycypacyjnego w Polsce skorzystało miast Sopot w 2011 r.. Natomiast miasto Rzeszów, którego mieszkańcy byli uczestnikami prezentowanych w artykule badań realizuje tę ideę od 2013 roku.

${ }^{11}$ Zob. http://www.budzetobywatelski.elblag.eu/uploads/static/files/Ankieta-Budzet-obywatelskiw-Elblagu.pdf

12 Zob. http://www.kornik.pl/Image/files/aktualnosci/Ankieta\%20Ewaluacyjna-wer\%20ost.pdf

${ }_{13}$ Zob. http://www.interankiety.pl/interankieta/3d371800139949b735f32c6fe44fd297

${ }^{14}$ Zob. http://myslowice.pl/data/investFiles/wyniki_badania_ankietowego.pdf
} 
Poznań ${ }^{15}$, Pszczyna ${ }^{16}$ czy Wrocław ${ }^{17}$. Problematyka budżetu partycypacyjnego pojawia się również jako zagadnienia poboczne badań dotyczących społeczeństwa obywatelskiego ${ }^{18}$.

Podkreślenia wymaga fakt, że aktualnie w polskiej literaturze przedmiotu nie można odnaleźć wyników kompleksowych badań dotyczących zagadnień związanych z budżetem partycypacyjnym, które swoim zasięgiem obejmowałyby większy obszar niż jedna jednostka samorządowa. Trzeba również zaznaczyć, że wyniki badań dotyczących budżetu partycypacyjnego pochodzące $\mathrm{z}$ innych państw są trudne do bezpośredniego porównania chociażby z powodu obowiązujących różnic w przepisach prawnych czy uwarunkowań historyczno-społeczno-kulturowych, które w sposób bezpośredni wpływają na postawę lokalnych społeczności w tym zakresie.

Badania ankietowe dotyczących problematyki „Aktywności członków lokalnej społeczności miasta Rzeszowa w zakresie budżetu partycypacyjnego" przeprowadzono na grupie 643 respondentów w wieku powyżej 16 lat, którzy posiadają stałe lub czasowe zameldowanie w mieście Rzeszowie, a tym samym prawo do udziału w głosowaniu na projekty w ramach Rzeszowskiego Budżetu Obywatelskiego (RBO). Badania ankietowe przeprowadzono w miesiącu czerwcu 2016 roku. Zostały one poprzedzone badaniem pilotażowym wykonanym w miesiącu kwietniu 2016 roku.

Analizowana grupa badawcza składała się z 327 kobiet $(50,85 \%)$ oraz 316 mężczyzn $(49,15 \%)$. Uczestnicy badań zostali podzieleni przy równoczesnym wykorzystaniu kryterium płci i wieku na dwanaście segmentów badawczych.

W artykule zaprezentowano wybrane wyniki badań dotyczące czterech segmentów, tj. dwóch analizowanych grup wiekowych ankietowanych (grupy wiekowej 36-45 lat oraz grupy wiekowej 46-55 lat ${ }^{19}$ ). W składzie analizowanej w artykule grupy badawczej znajdowały się 223 osoby (114 kobiet oraz 109 mężczyzn), które w oparciu o kryterium ich wieku można zakwalifikować do pokolenia $\mathrm{X}^{20}$.

Podstawowym celem artykułu była próba oceny znajomości zagadnień związanych z budżetem partycypacyjnym przez członków lokalnej społeczności zaliczanych do pokolenia X oraz sprawdzenie stanu ich aktywności w tym zakresie.

15 Zob. www.poznan.pl/mim/public/main/attachments.html?co...pl...

${ }^{16}$ Zob. http://pobierz.pless.pl/2015/12/pszczynski_budzet_obywatelski_ankieta.pdf

17 Zob. https://www.wroclaw.pl/ocen-wbo2015/ankieta-wyniki

18 Zob. np. Dialog obywatelski w Krakowie $w$ opiniach mieszkańców, przedstawicieli organizacji pozarzadowych i mediów.

19 Wydzielenie w ramach analizowanego pokolenia X dwóch segmentów wiekowych miało na celu sprawdzenie czy w grupie osób, zaliczanych do jednego pokolenia, które może dzieli nawet 20-letnia różnica wieku występuje w wyodrębnionych grupach wiekowych zbliżony poziom wiedzy i aktywności w zakresie budżetu obywatelskiego.

${ }^{20} \mathrm{~W}$ literaturze przedmiotu nie ma sztywnych dat określających pokolenie X. Do pokolenia X na świecie zaliczane są osoby, które urodziły się po 1961 r. (1965 r.) a nie później niż w 1979 r. (1984 r.), a w Polsce osoby urodzone między 1961 r. a 1983 r. (1985 r.). Zob. W. Strauss, N. Howe, Generations: the history of America's future, 1584 to 2069. William Morrow, New York 2008. 


\section{OCENA STANU ZNAJOMOŚCI IDEI BUDŻETU PARTYCYPACYJNEGO WŚRÓD ANKIETOWANYCH}

Analiza wyników badań ankietowych pozwoliła stwierdzić, że wśród ankietowanych zaliczanych do grupy wiekowej 36-55 lat istnieje wysoka świadomość występowania idei budżetu partycypacyjnego (rys. 1).

Średni poziom świadomości w tej grupie wyniósł 77,68\%. Najwyższy poziom był w segmencie kobiet $\mathrm{w}$ wieku $46-55$ lat $(78,18 \%)$ a najniższy wśród kobiet $\mathrm{z}$ segmentu wiekowego 36-45 lat (74,57\%). Należy również zaznaczyć, że wyższą świadomość na ten temat niezależnie od płci respondentów posiadały osoby z grupy wiekowej 46-55 lat.

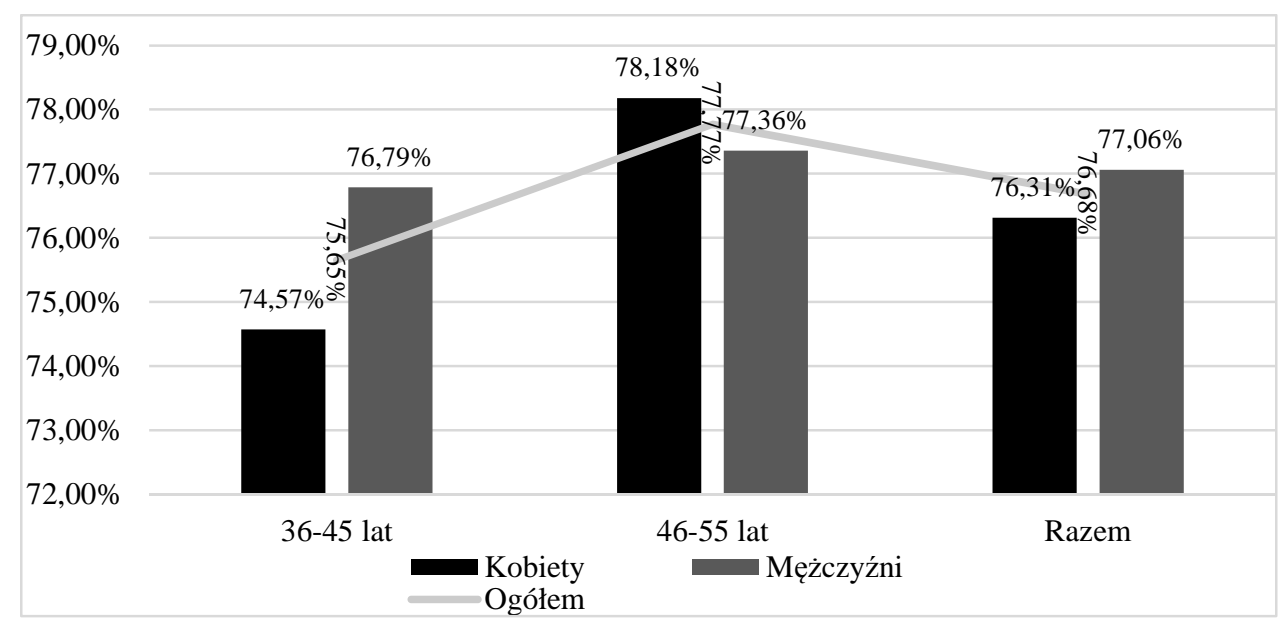

Rys. 1. Poziom znajomości idei budżetu partycypacyjnego wśród respondentów

Źródło: opracowanie na podstawie badań własnych.

Niestety, wysoka świadomość występowania idei budżetu partycypacyjnego nie przekładała się na wysoki poziom wiedzy na temat zasad jego funkcjonowania. Ponad $40 \%$ ankietowanych (40,23\% kobiet oraz 42,86\% mężczyzn) dokonując samooceny poziomu wiedzy na temat zasad funkcjonowania budżetu obywatelskiego wybrało odpowiedzi znikomy lub mały (rys. 2). Niżej swój poziom wiedzy oceniali ankietowani z grupy wiekowej 46-55 lat $(48,81 \%)$ niż respondenci z grupy wiekowej 36-45 lat $(34,48 \%)$.

Tylko co czwarty uczestnik badań uważał, że posiada wysoki poziom wiedzy w tym zakresie. Potwierdzeniem tego było wskazanie przez 23,39\% respondentów odpowiedzi duży i bardzo duży. Należy zaznaczyć, że wyżej swój poziom wiedzy oceniali mężczyźni $(27,38 \%)$ niż kobiety $(19,54 \%)$.

Bezpośredni wpływ na taki poziom wiedzy ankietowanych mają źródła, z jakich pozyskiwali oni informacje na temat zasad funkcjonowania budżetu partycypacyjnego (rys. 3).

Podstawowym źródłem wiedzy dla uczestników badań są informacje uzyskane od osób z najbliższego otoczenia ankietowanych tj. członków rodzin $(66,08 \%)$ oraz znajomych/sąsiadów $(50,88 \%)$. Z informacji pozyskanych od członków rodziny częściej korzystają mężczyźni $(70,24 \%)$ niż kobiety $(62,07 \%)$ oraz ankietowani z grupy wiekowej 
46-55 lat $(70,24 \%)$ niż respondenci $z$ grupy wiekowej 36-45 lat (62,7\%). Natomiast z wiedzy przekazywanej przez znajomych/sąsiadów częściej korzystali mężczyźni $(54,76 \%)$ niż kobiety $(47,13 \%)$ oraz ankietowani $z$ grupy wiekowej $36-45$ lat $(55,17 \%)$ niż respondenci z grupy wiekowej 46-55 lat (46,43\%).

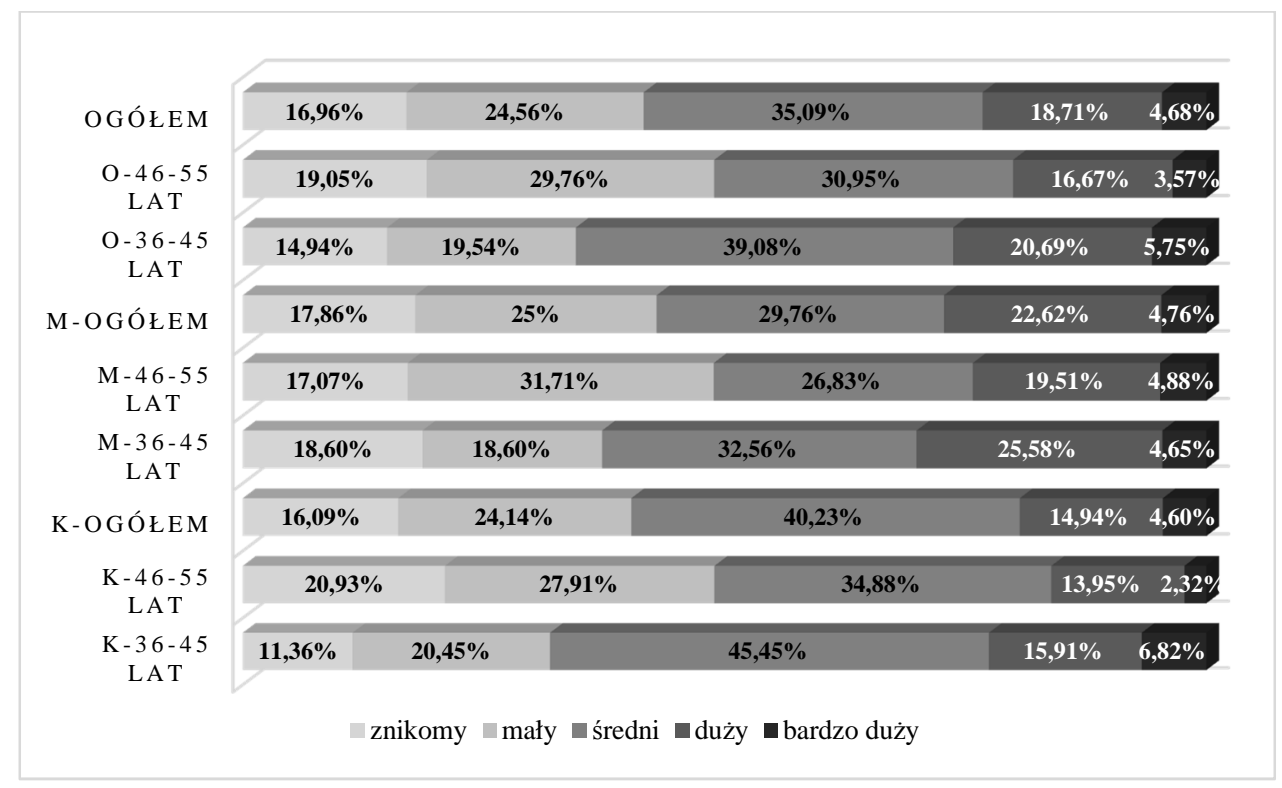

Rys. 2. Samoocena poziomu wiedzy respondentów na temat budżetu partycypacyjnego ${ }^{21}$

Źródło: opracowanie na podstawie badań własnych.

Prawie połowa uczestników badań zadeklarowała, że pozyskała informacje na temat zasad funkcjonowania budżetu obywatelskiego z Internetu. Z tego źródła informacji częściej korzystali mężczyźni $(52,38 \%)$ niż kobiety $(45,98 \%)$ oraz ankietowani z grupy wiekowej 36-45 lat $(52,87 \%)$ niż respondenci z grupy wiekowej 46-55 lat $(45,24 \%)$. Należy również zaznaczyć, że z informacji znajdujących się na Portalu miasta Rzeszowa najczęściej korzystali ankietowani mężczyźni z grupy wiekowej 36-45 lat (30,23\%), a z informacji znajdujących się na portalach społecznościowych kobiety z grupy wiekowej 36-45 lat $(31,82 \%)$.

Stosunkowo niewielka grupa ankietowanych zadeklarowała, że pozyskała informacje z tradycyjnych środków masowego przekazu - telewizji $(11,11 \%)$, prasy $(11,11 \%)$ oraz radia $(7,02 \%)$. Ze wszystkich tych źródeł informacje częściej pozyskiwali mężczyźni niż kobiety. Natomiast analizując wykorzystanie tych źródeł informacji przez przedstawicieli poszczególnych analizowanych segmentów należy stwierdzić, że z informacji radiowych i prasowych częściej korzystali badani z segmentu wiekowego 36-45 lat, a z informacji telewizyjnych respondenci z segmentu wiekowego 46-55 lat.

${ }^{21}$ Oznaczenia na wykresach K - kobiety, M - mężczyźni, O - ogółem. Np. K - 36-45 lat - kobiety $\mathrm{z}$ grupy wiekowej $36-45$ lat. 


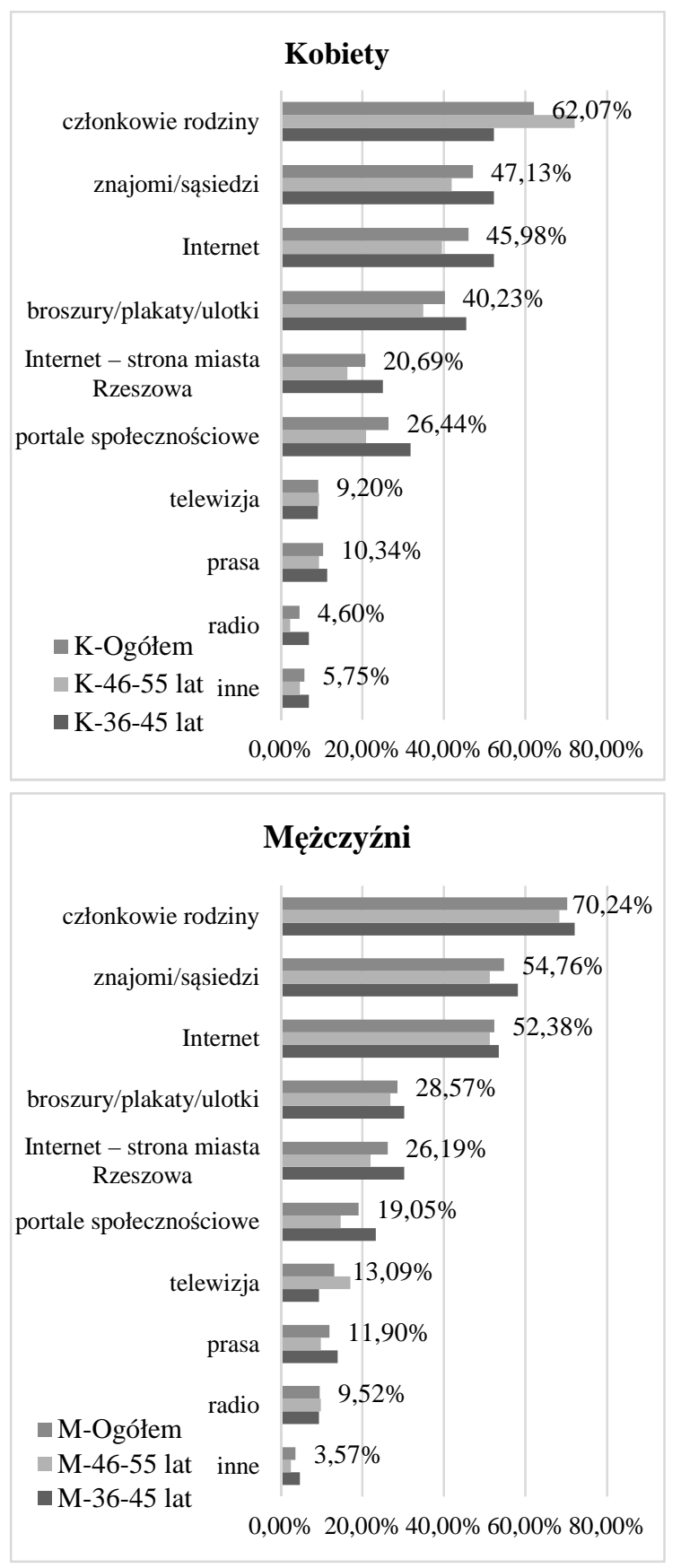

Rys. 3. Źródła, z jakich pozyskiwali wiedzę na temat budżetu partycypacyjnego uczestnicy badań Źródło: opracowanie na podstawie badań własnych. 
Trzeba również zaznaczyć, że w analizowanej grupie badawczej swoją wiedzę na temat zasad funkcjonowania budżetu obywatelskiego poszerzyło o informacje zawarte w literaturze fachowej tylko 4,68\% ankietowanych. Częściej po tego typu źródła sięgały kobiety $(5,75 \%)$ niż mężczyźni $(3,57 \%)$.

\section{OCENA AKTYWNOŚCI ANKIETOWANYCH W ZAKRESIE UDZIAŁU W RZESZOWSKIM BUDŻECIE OBYWATELSKIM}

Idea Rzeszowskiego Budżetu Obywatelskiego jest wykorzystywana w praktyce od 2013 roku. Dotychczas odbyły się głosowania na jego cztery edycje. Przeprowadzone badania pozwoliły stwierdzić, że udział ankietowanych w głosowaniach na kolejne edycje RBO systematycznie wzrastał (rys. 4).

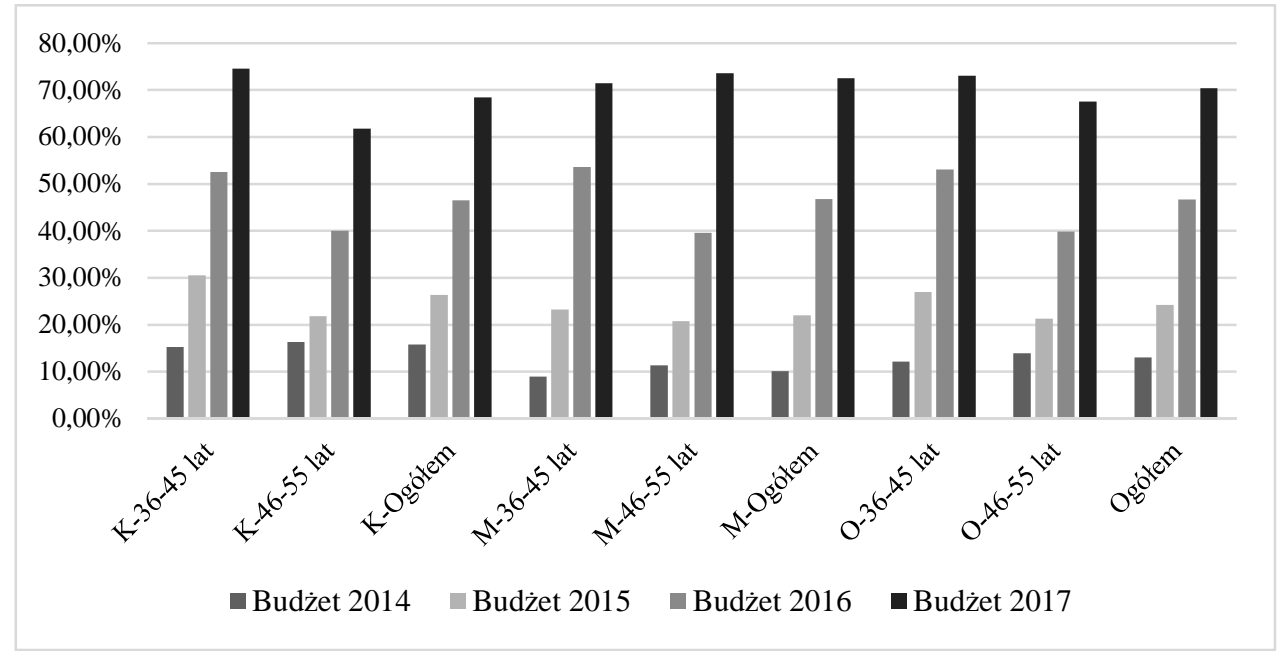

Rys. 4. Procentowy udział w głosowaniu na Rzeszowski Budżet Obywatelski w kolejnych edycjach uczestników badań

Źródło: opracowanie na podstawie badań własnych.

W pierwszej edycji udział w głosowaniu wzięło $13 \%$ ankietowanych, w drugiej edycji 24,21\% respondentów, w trzeciej edycji 46,64\% badanych, a w czwartej aż 70,4\% uczestników badań. W dwóch pierwszych edycjach głosowania większym udziałem wykazały się kobiety, a w kolejnych edycjach mężczyźni. Od drugiej edycji głosowania większym udziałem wykazali się ankietowani z grupy wiekowej 36-45 lat.

Trzeba jednak zaznaczyć, że wysoki procentowy udział w głosowaniach na projekty zgłoszone do RBO nie pokrywał się z chęcią zapoznania się z ich szczegółami przez osoby na nie głosujące (rys. 5). Ponad $62 \%$ osób, które oddały swój głos na RBO nie zadawało sobie trudu, aby zapoznać się ze szczegółami zgłoszonych projektów, w tym również ze szczegółami zadań, na które oddały swój głos. Najczęściej ze szczegółami projektów przed głosowanie zapoznawały się kobiety z grupy wiekowej 46-55 lat (41,18\%), a najrzadziej mężczyźni z grupy wiekowej 46-55 lat (33,33\%). 


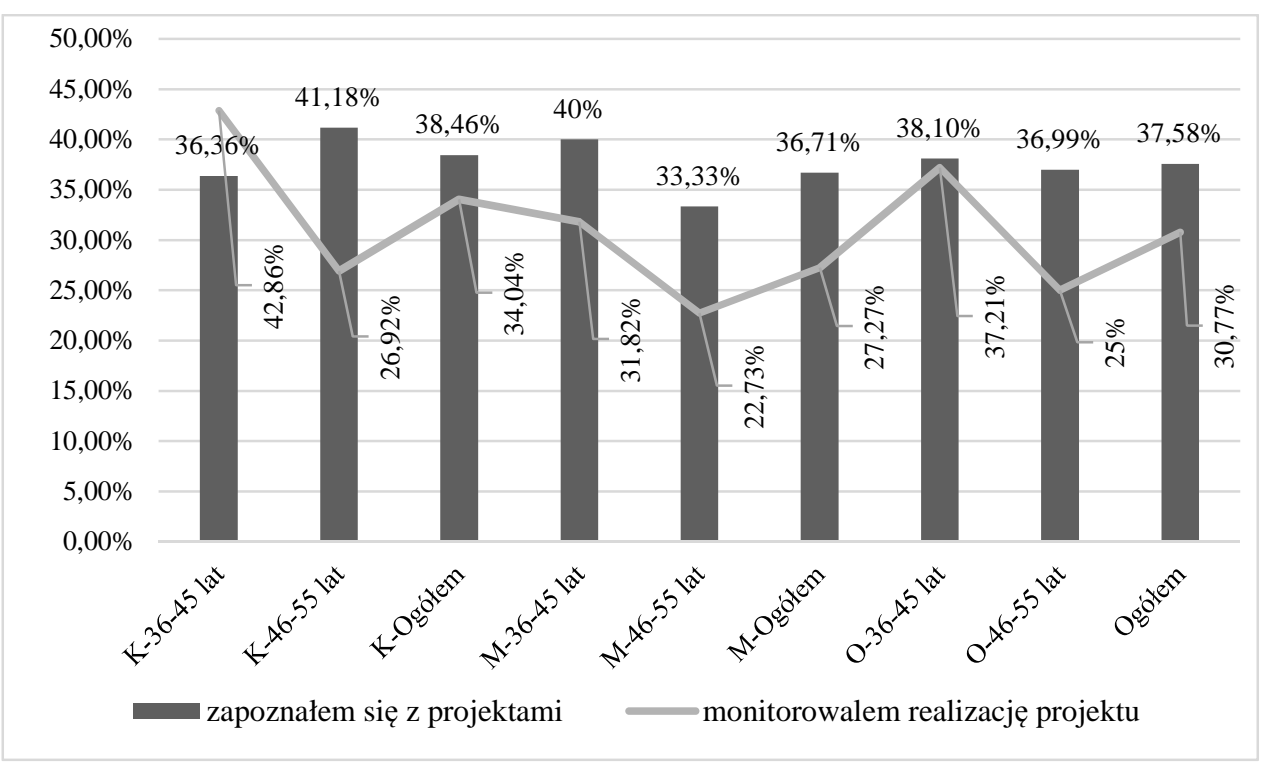

Rys. 5. Zapoznanie się ze szczegółami projektów oraz monitorowanie ich realizacji przez ankietowanych

Źródło: opracowanie na podstawie badań własnych.

Analiza determinantów posiadających wpływ na niezapoznanie się ze szczegółami projektów przed oddaniem na nie głosu (rys. 6) pozwoliła stwierdzić, że podstawowym powodem takiego zachowania ankietowanych był fakt, iż zaufali oni opinii osób rekomendujących projekt $(76,53 \%)$. Opinie takie były bardziej istotne dla kobiet $(81,25 \%)$ niż dla mężczyzn (72\%) oraz dla osób z segmentu wiekowego 46-55 lat $(82,61 \%)$ niż dla ankietowanych z segmentu wiekowego 36-45 lat $(71,15 \%)$.

Jako drugi powód takiego zachowania ankietowani wskazywali trudności w uzyskaniu informacji na ten temat. Potwierdza to wybór przez respondentów odpowiedzi nie wiedziałem, gdzie szukać informacji (53,06\%) oraz brak reklamy projektów (39,8\%). Obie te odpowiedzi najczęściej były wskazywane przez kobiety z grupy wiekowej 46-55 lat (odpowiednio nie wiedziałem, gdzie szukać informacji (65\%) oraz brak reklamy projektów $(55 \%))$.

W tym miejscu należy zaznaczyć, że powyższe odpowiedzi kłóciły się z odpowiedziami udzielonymi na pytanie, jak ankietowani oceniają dostępne informacje na temat projektów zgłoszonych do RBO. 56,95\% respondentów (50\% kobiet oraz 64,22\% mężczyzn) stwierdziło, że ocenia jakość tych informacji na poziomie co najmniej dobrym.

Trzeba również zaznaczyć, że ankietowani nie tylko nie zapoznawali się ze szczegółami projektów przed oddaniem na nie swojego głosu, ale również nie monitorowali realizacji projektów, na które oddali swój głos (rys. 5). Brak zainteresowania monitorowaniem projektów wskazało prawie $70 \%$ ankietowanych (62,79\% osób z segmentu 36-45 lat oraz $75 \%$ osób z segmentu 46-55 lat). Największe zainteresowanie przebiegiem realizacji projektów, na które oddały swój głos w ramach RBO wykazywały kobiety z grupy wie- 
kowej 36-45 lat (42,86\%), a najmniejsze mężczyźni z grupy wiekowej 46-55 lat $(22,73 \%)$.

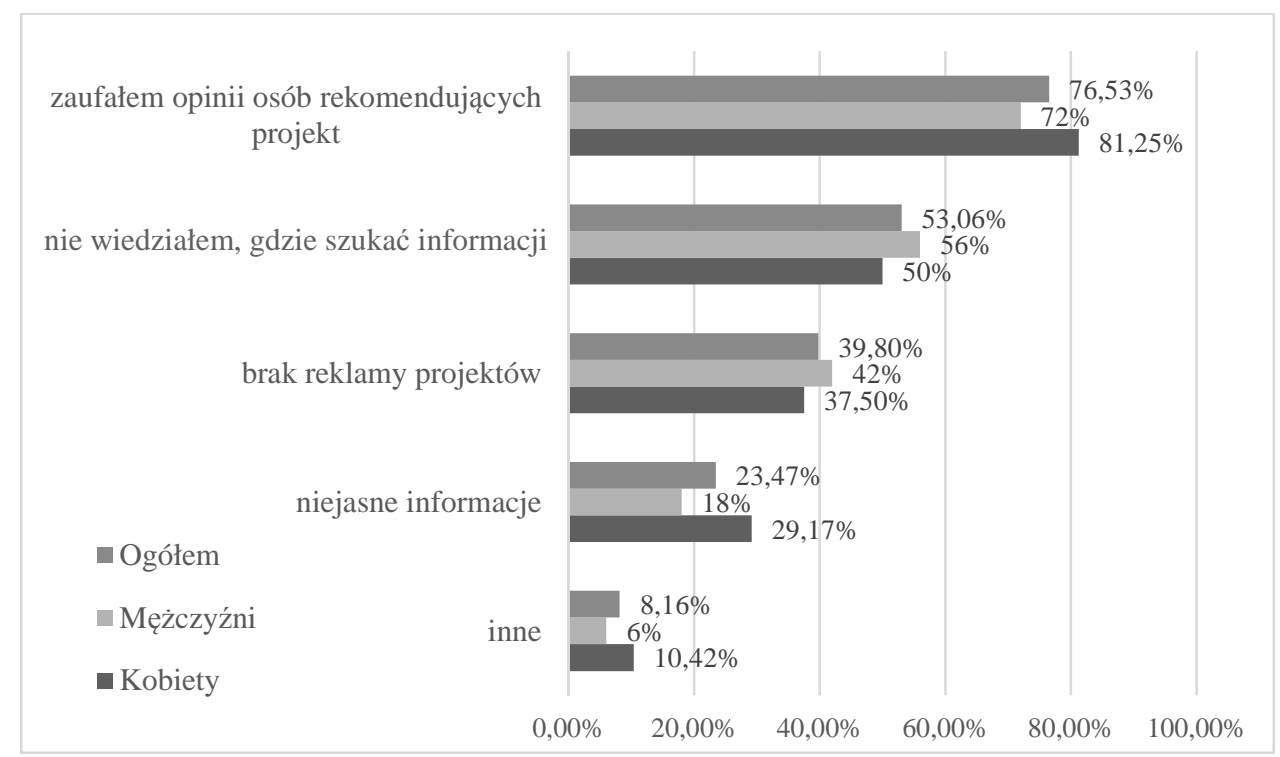

Rys. 6. Czynniki, jakie miały wpływ na niezapoznanie się z projektami przez respondentów Źródło: opracowanie na podstawie badań własnych.

\section{CZYNNIKI WPLYWAJACEE NA UDZIAŁ ANKIETOWANYCH W RZESZOWSKIM BUDŻECIE OBYWATELSKIM}

Analiza czynników determinujących udział w głosowaniu przedstawicieli analizowanego segmentu wiekowego na RBO pozwoliła stwierdzić, że dwoma podstawowymi powodami podjęcia takich działań była chęć pomocy danej instytucji/organizacji/ społeczności $(70,76 \%)$ oraz fakt, że ankietowani zostali o to poproszeni $(64,91 \%)$. Trzeba zaznaczyć, że w przypadku tych odpowiedzi uwidoczniły się znaczne różnice w poziomie ich istotności zarówno wśród przedstawicieli poszczególnych płci, jak i grup wiekowych respondentów (rys. 7).

Chęć pomocy danej instytucji/organizacji/społeczności była bardziej istotna dla kobiet $(74,71 \%)$ niż dla mężczyzn $(66,98 \%)$ oraz dla ankietowanych z grupy wiekowej 36-45 lat $(75,86 \%)$ niż dla respondentów z grupy wiekowej $46-55$ lat $(65,48 \%)$. Natomiast fakt, że ankietowani zostali poproszeni o oddanie swojego głosu na projekty RBO był częściej bodźcem do takiego zachowania dla mężczyzn $(73,81 \%)$ niż kobiet $(56,32 \%)$ oraz dla ankietowanych z grupy wiekowej 46-55 lat $(77,38 \%)$ niż respondentów z grupy wiekowej 36-45 lat $(52,87 \%)$.

Kolejnymi czynnikami, które posiadają wpływ na udział ankietowanych w głosowaniu na RBO był fakt, że respondentom podoba się idea budżetu partycypacyjnego $(17,54 \%)$ oraz chęć aktywnego udziału w życiu lokalnych społeczności $(16,96 \%)$. 


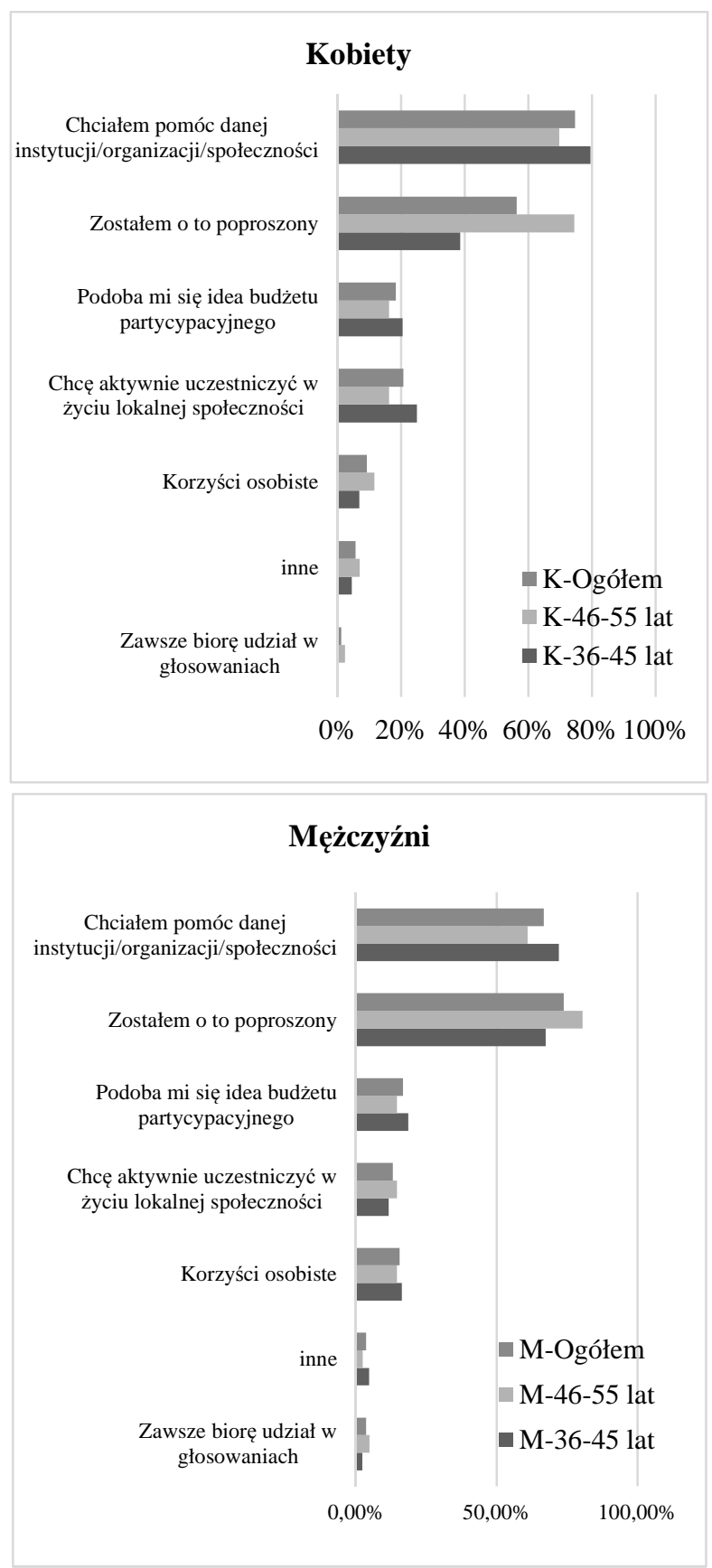

Rys. 7. Czynniki wpływające na udział respondentów w głosowaniu na Rzeszowski Budżet Obywatelski

Źródło: opracowanie na podstawie badań własnych. 
Idea budżetu partycypacyjnego znalazła więcej zwolenników wśród biorących udział w badaniach kobiet $(18,39 \%)$ niż mężczyzn $(16,67 \%)$ oraz wśród ankietowanych z grupy wiekowej 36-45 lat $(19,54 \%)$ niż respondentów z grupy wiekowej 46-55 lat $(15,48 \%)$. Podobnie sytuacja przedstawiała się w przypadku odpowiedzi chcę aktywnie uczestniczyć $w \dot{z} y c i u$ lokalnych społeczności. Odpowiedź tę częściej wskazywały kobiety $(20,69 \%)$ niż mężczyźni $(13,09 \%)$ oraz ankietowani z grupy wiekowej 36-45 lat $(18,39 \%)$ niż respondenci 46-55 lat $(15,48 \%)$.

W analizowanej grupie badawczej znalazła się również grupa respondentów, która liczyła, że oddając głos na RBO będzie mogła osiągnąć korzyści osobiste (12,28\%). Odpowiedź ta była częściej wskazywana przez mężczyzn $(15,48 \%)$ niż kobiety $(9,19 \%)$ oraz przez ankietowanych z grupy wiekowej 46-55 lat $(13,09 \%)$ niż respondenci z grupy wiekowej 36-45 lat (11,49\%). Trzeba zaznaczyć, że najbardziej na osiągniecie korzyści osobistych liczyli ankietowani mężczyźni zaliczani do segmentu 36-45 lat (16,28\%).

Uwzględniając, że tylko 16,37\% ankietowanych (13,79\% kobiet oraz 19,05\% mężczyzn) stwierdziło, że decyzje o wzięciu udziału w głosowaniu na RBO podjęło samodzielnie oraz że 64,91\% respondentów wskazało, iż bodźcem do tego udziału była prośba innych osób. Zbadano, kto posiadał wpływ w tym zakresie na uczestników badań (rys. 8). Analiza odpowiedzi pozwoliła stwierdzić, że największy wpływ na ankietowanych miały prośby współmałżonków (52,05\%-49,42\% kobiety oraz 54,76\% mężczyźni) oraz koleżanek/kolegów (45,61\%-43,68\% kobiety oraz 47,62\% mężczyźni). Trzeba zaznaczyć, że na prośby zarówno współmałżonków, jak i koleżanek/kolegów częściej pozytywnie reagowali przedstawiciele segmentu wiekowego 36-45 lat.

$\mathrm{Na}$ oddanie głosu przez co piątego uczestnika badań wpływ posiadały jego dzieci (21,05\% - 9,54\% kobiety oraz 22,62\% mężczyźni) oraz pracodawca $(19,98 \%$ - 14,94\% kobiety oraz $25 \%$ mężczyźni). Trzeba zaznaczyć, że pracodawcy częściej oddziaływali na decyzję ankietowanych z grupy wiekowej 36-45 lat $(24,14 \%)$ niż respondentów z grupy wiekowej 46-55 lat $(15,48 \%)$.

$\mathrm{Na}$ ankietowanych wpływ posiadali również inni członkowie ich rodzin - rodzeństwo $(9,94 \%)$ oraz rodzice $(7,6 \%)$. Rodzeństwo największy wpływ miało na decyzje kobiet z grupy wiekowej 36-45 lat $(13,64 \%)$, a rodzice na mężczyzn z grupy wiekowej 36-45 lat $(11,63 \%)$.

W trakcie badań przeanalizowano również czynniki determinujące oddanie głosu przez ankietowanych na konkretne zadanie (rys. 9). Wyniki tej analizy pozwoliły stwierdzić, że dla respondentów najważniejsza jest chęć poparcia projektów promowanych przez szkoły, przedszkola oraz organizacje charytatywne czyli projekty, których realizacja może znacząco poprawić infrastrukturę z której w pierwszej kolejności korzystają ich dzieci $(64,33 \%)$. Odpowiedź tę częściej wskazywały kobiety $(67,82 \%)$ niż mężczyźni $(60,71 \%)$ oraz ankietowani z segmentu wiekowego 36-45 lat $(62,07 \%)$ niż respondenci z segmentu wiekowego 46-55 lat (55,95\%).

Dla blisko $60 \%$ ankietowanych na wybór konkretnego projektu, na jaki oddali swój głos miały wpływ opinie członków najbliższej rodziny. Na sugestie ze strony członków najbliższej rodziny bardziej podatni byli mężczyźni $(61,9 \%)$ niż kobiety $(56,32 \%)$ oraz ankietowani $\mathrm{z}$ grupy wiekowej $36-45$ lat $(62,07 \%)$ niż respondenci $\mathrm{z}$ grupy wiekowej 46-55 lat $(55,95 \%)$. 


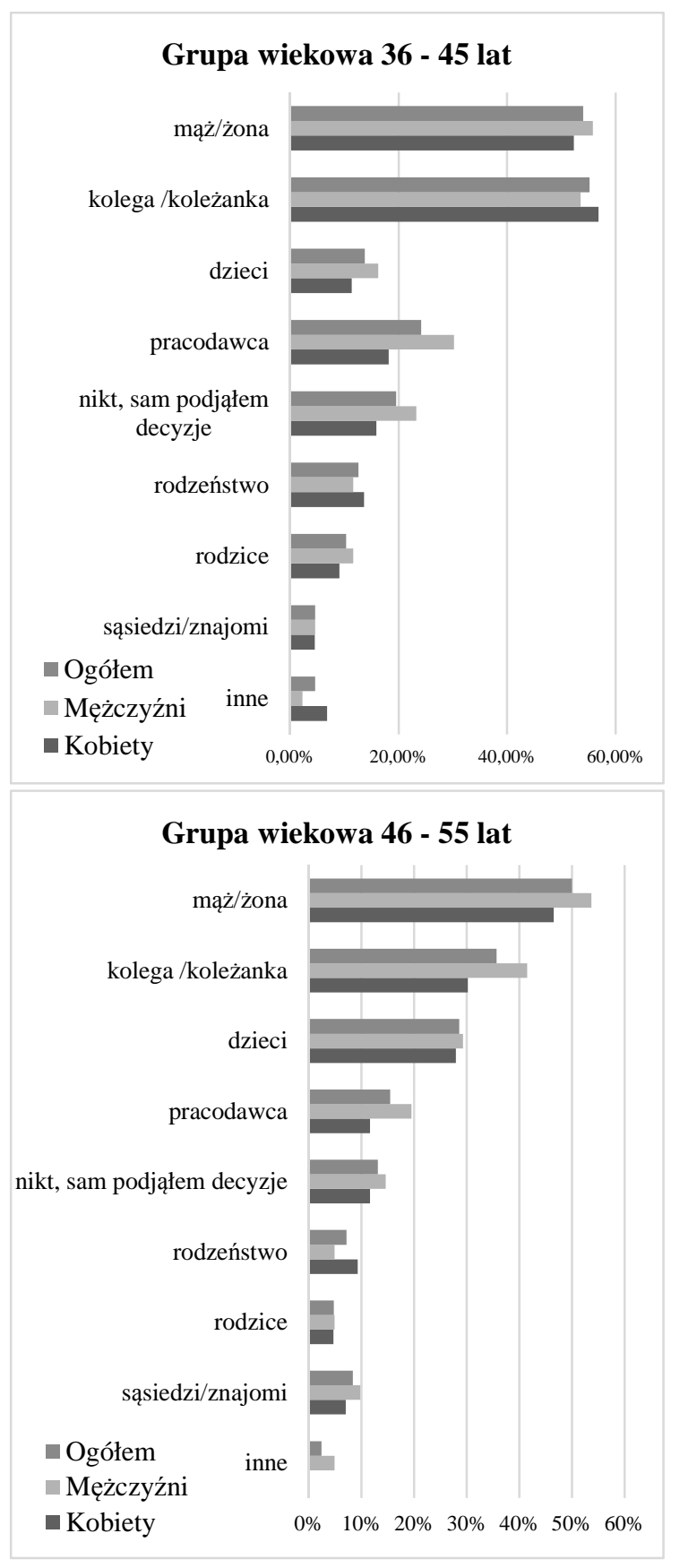

Rys. 8. Osoby posiadające wpływ na udział ankietowanych w głosowaniu na Rzeszowski Budżet Obywatelski

Źródło: opracowanie na podstawie badań własnych 

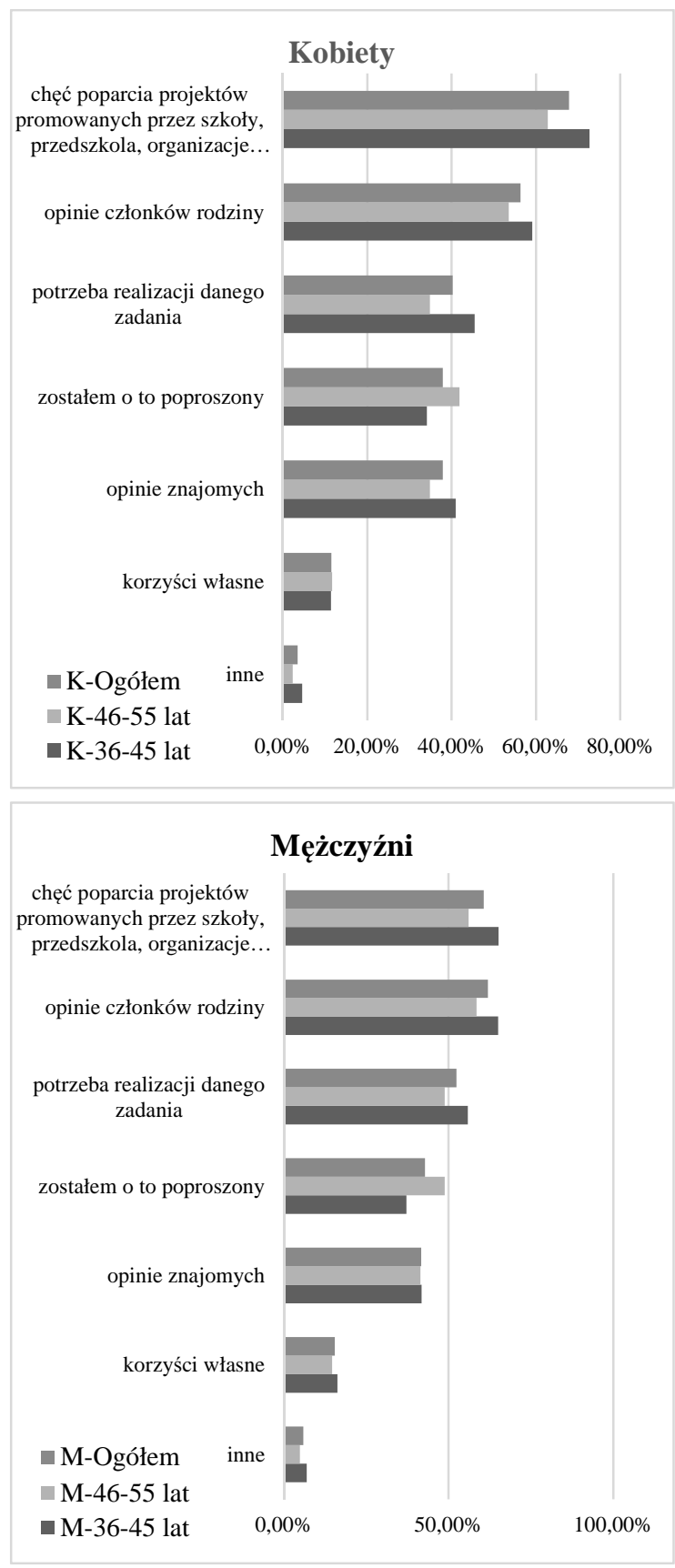

Rys. 9. Czynniki wpływające na oddanie głosu na konkretne zadanie przez ankietowanych w głosowaniu na RBO

Źródło: opracowanie na podstawie badań własnych. 
$\mathrm{Na}$ trzecim miejscu uczestnicy badań wskazali, że czynnikiem determinującym ich wybór była potrzeba realizacji danego zadania $(46,2 \%)$. Odpowiedź tę wskazywali częściej mężczyźni $(52,38 \%)$ niż kobiety $(40,23 \%)$ oraz ankietowani z segmentu 36-45 lat (50,57\%) niż respondenci z segmentu 46-55 lat (41,67\%).

Jako kolejny powód wyboru danego projektu respondenci wskazali, że zostali o to poproszeni $(40,35 \%)$. Większą podatność na prośby innych osób wykazywali mężczyźni $(42,86 \%)$ niż kobiety $(37,93 \%)$ oraz badani z grupy wiekowej $46-55$ lat $(45,24 \%)$ niż respondenci z grupy wiekowej $36-45$ lat $(35,63 \%)$.

\section{PODSUMOWANIE}

Władze poszczególnych jednostek samorządowych mając na uwadze rozwój jednostki oraz wzrost poziomu życia jej mieszkańców często sięgają po narzędzia, które zostały już $\mathrm{w}$ praktyce $\mathrm{z}$ powodzeniem wykorzystane przez inne samorządy. Przykładem takiego narzędzia jest właśnie idea budżetu partycypacyjnego. Ten brazylijski eksperyment w ciągu trzech dekad został wykorzystany przez władze jednostek samorządowych na wszystkich kontynentach. W 2010 r. z idei budżetu partycypacyjnego korzystało już ok. 2778 samorządów (w Europie ok. 1317, w Ameryce ok. 1138, w Azji ok. 109) ${ }^{22}$. Polskie samorządy zaczęły wykorzystywać tę ideę od 2011 roku.

Władze samorządowe upatrują, że poprzez wykorzystanie tej idei może nastąpić ich zbliżenie $\mathrm{z}$ obywatelami, większe zrozumienie procedur związanych $\mathrm{z}$ finansowaniem zadań samorządowych, przeniesienie części odpowiedzialności na lokalne społeczności a przez to uzyskanie większego zrozumienia dla ich pracy oraz poprawa ich wizerunku w oczach mieszkańców, czyli wyborców.

Mieszkańcom natomiast idea ta stwarza ograniczoną możliwość wpływania na to, jakie zadania w danym roku zostaną przyjęte do realizacji. Wpływa ona na ich aktywność i chęć udziału w życiu lokalnych społeczności.

Przeprowadzone badania pozwoliły stwierdzić, że wśród respondentów zaliczanych do grupy wiekowej 36-55 lat, czyli reprezentantów pokolenia X mieszkających na terenie jednostki samorządowej, gdzie idea budżetu obywatelskiego jest realizowana od kilku lat znajomość jej jest stosunkowo wysoka (ok. 77\%, w tym 76,31\% kobiety oraz 77,06\% mężczyźni). Chociaż zauważalna jest potrzeba zwiększenia działań mających na celu poprawę stanu wiedzy mieszkańców na temat zasad funkcjonowania budżetu obywatelskiego. Należy zaznaczyć, że ponad 40\% uczestników badań (40,23\% kobiet oraz $42,86 \%$ mężczyzn) swój poziom wiedzy na ten temat określiło jako znikomy lub mały, a tylko niewiele ponad $23 \%$ respondentów (19,54\% kobiet oraz $27,38 \%$ mężczyzn) uważało, że jest on duży lub bardzo duży.

Zdecydowana większość uczestników badań (85,2\%-81,58\% kobiet oraz 88,99\% mężczyzn) jest zdania, że w mieście Rzeszowie powinny być realizowane kolejne edycje budżetu obywatelskiego. Wśród mieszkańców występuje duże zainteresowanie udziałem

\footnotetext{
${ }^{22}$ Y. Sintomer, C. Herzberg, A. Röcke, G. Allegretti, Transnational Models of Citizen Participation: The Case of Participatory Budgeting [in:] N. Dias (org), Hope for Democracy - 25 Years of Participatory Budgeting Worldwide. IN LOCO ASSOCIATION, SÃO BRÁS DE ALPORTEL, 2014, s. 30; Y. Sintomer, C. Herzberg, G. Allegretti, A. Röcke, M. Alves, Participatory Budgeting Worldwide - Updated Version. Dialog Global No. 25, ENGAGEMENT GLOBAL gGmbH, Bonn, November 2013, s. 14.
} 
w głosowaniach na zadania zgłoszone do RBO. Prawie $70 \%$ ankietowanych deklarowało chęć udziału w głosowaniach w kolejnych edycjach RBO (rys. 10). Należy jednak zaznaczyć, że większą aktywność w tym zakresie zgłaszają kobiety $(71,05 \%)$ niż mężczyźni $(66,97 \%)$. Dla $74 \%$ respondentów, którzy oddali w poprzednich latach głos na projekty przyjęte do realizacji fakt ten miał pozytywny wpływ na ich decyzje o udziale w głosowaniu w kolejnych edycjach. Przyjęcie do realizacji projektu było bardziej istotne dla mężczyzn $(75 \%)$ niż kobiet $(72,34 \%)$ Należy równocześnie stwierdzić, że fakt nieprzyjęcia do realizacji projektu $\mathrm{w}$ poprzednich latach wpłynął negatywnie na chęć wzięcia udziału w głosowaniu tylko na $28 \%$ respondentów, którzy głosowali na te projekty. Nieprzyjęcie do realizacji projektu zniechęcało do udziału w kolejnych edycjach RBO większą grupę kobiet $(32,26 \%)$ niż mężczyzn $(25,71 \%)$.

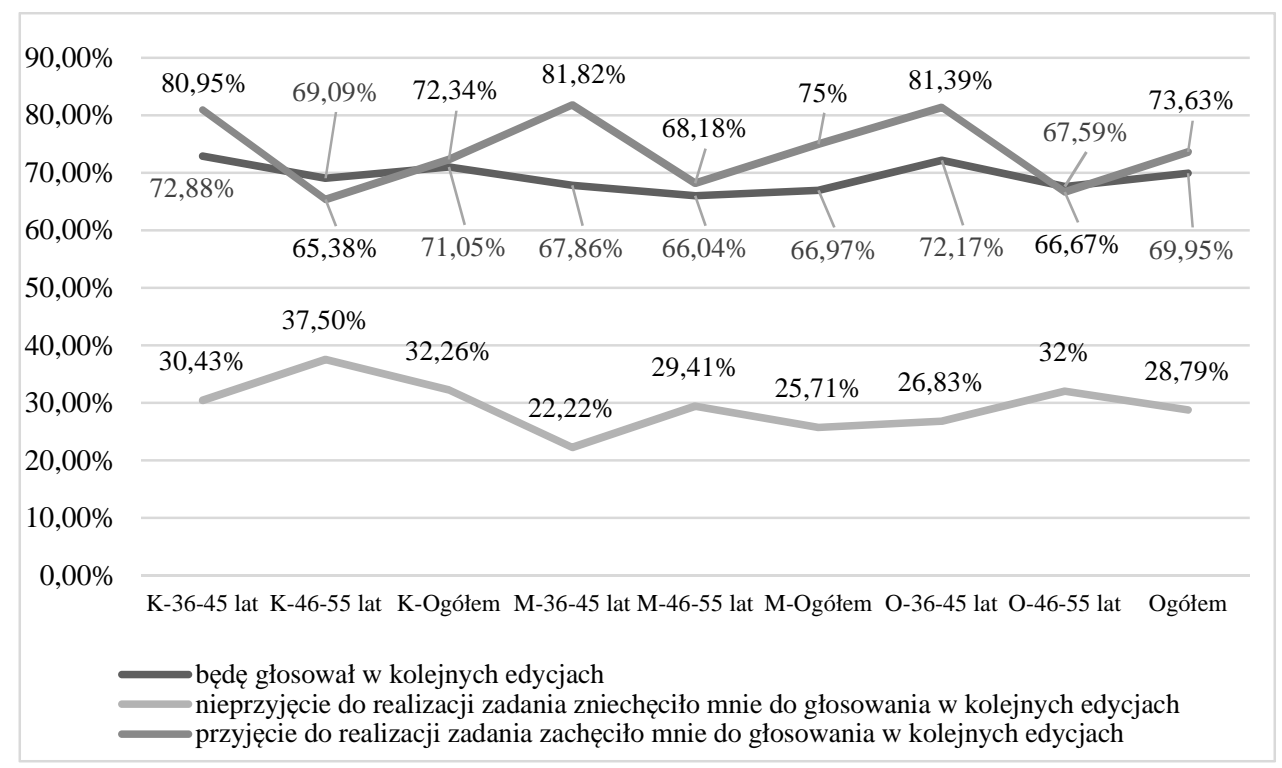

Rys. 10. Deklarowane zachowanie ankietowanych w przyszłych edycjach RBO

Źródło: opracowanie na podstawie badań własnych.

Na podkreślenie zasługuje fakt, że mieszkańcy swój udział w działaniach związanych z realizacją budżetu obywatelskiego zazwyczaj ograniczają do oddania głosu na zgłoszone projekty, czyli przyjmują postawę bierną. Tylko niewielka grupa stara się bardziej aktywnie włączyć się do prac nad budżetem obywatelskim - zgłaszając projekty lub będąc członkami grup inicjatywnych. W analizowanej grupie badawczej w składzie grup inicjatywnych znajdowało się 4,04\% ankietowanych (5,31\% kobiet oraz 2,75\% mężczyzn). Natomiast wśród zgłaszających projekty znalazło się $0,45 \%$ badanych $(0,88 \%$ kobiet oraz $0 \%$ mężczyzn).

Przeprowadzone badania pozwoliły również wykazać, że analiza stanu wiedzy i aktywności przedstawiciele danego pokolenia, w tym przypadku pokolenia X obejmującego osoby, których różnica wieku może wynosić ponad 20 lat, nie powinna być przeprowa- 
dzana wyłącznie dla całego pokolenia. Należy ją przeprowadzać z uwzględnieniem podziału respondentów na segmenty wiekowe. Potwierdzeniem tego jest m.in. fakt, że w grupie wiekowej 36-45 lat, niezależnie od płci ankietowanych, mniejsza liczba respondentów deklarowała znajomość idei budżetu partycypacyjnego niż w grupie wiekowej 46-55 lat. Z kolei ankietowani z grupy wiekowej 36-45 lat ${ }^{23}$ deklarowali wyższy poziom wiedzy na ten temat niż ankietowani z grupy wiekowej $46-55$ lat $^{24}$.

Należy również zaznaczyć, że respondenci z grupy wiekowej 36-45 lat wykazywali się większą aktywnością w zakresie budżetu partycypacyjnego niż ankietowani z grupy wiekowej 46-55 lat. Częściej zapoznawali się ze szczegółami projektów ${ }^{25}$ oraz monitorowali ich realizację ${ }^{26}$. Zadeklarowali oni również wyższą chęć udziału w głosowaniach w kolejnych edycjach $\mathrm{RBO}^{27}$.

\section{Literatura}

[1] 72 Frequently Asked Questions about Participatory Budgeting, UN-HABITAT, Quito 2004.

[2] Lerner J., Participatory Budgeting Building Community Agreement Around Tough Budget Decisions, "National Civic Review" 2011, Vol. 100, Issue 2.

[3] Participatory Budgeting Worldwide - Updated Version. Dialog Global 25, Bonn, 2013.

[4] Shah A. (ed.), Participatory Budgeting, The World Bank, Washington, D.C. 2007.

[5] Sintomer Y., Röcke A., Herzberg C., Participatory Budgeting in Europe: Potentials and Challenges, "International Journal of Urban and Regional Research" 2008, Vol. 32, No. 1.

[6] Sintomer Y., Herzberg C., Allegretti G., Röcke A., Alves M., Participatory Budgeting Worldwide - Updated Version, "Dialog Global No. 25, ENGAGEMENT GLOBAL gGmbH”, Bonn, November 2013.

[7] Sintomer Y., Herzberg C., Röcke A., Allegretti G., Transnational Models of Citizen Participation: The Case of Participatory Budgeting [in:] N. Dias (org), Hope for Democracy - 25 Years of Participatory Budgeting Worldwide, IN LOCO ASSOCIATION, SÃO BRÁS DE ALPORTEL 2014.

[8] Spada P., The Economic and Political Effects of Participatory Budgeting, Prepared for delivery at the 2009 Congress of the Latin American Studies Association, Rio de Janeiro, Brazil June 11-14, 2009, http://citeseerx.ist.psu.edu/viewdoc/download?doi=10.1.1.505. 2726\&rep=rep1\&type $=$ pdf.

[9] Wampler B., A guide to participatory budgeting, 2000, http://www.internationalbudget. org/wp-content/uploads/A-Guide-to-Participatory-Budgets.pdf.

${ }^{23} \mathrm{~W}$ grupie wiekowej 36-45 lat 44,48\% ankietowanych zadeklarowało swój poziom wiedzy na temat budżetu partycypacyjnego jako znikomy lub mały, a 26,44\% jako duży lub bardzo duży.

${ }^{24} \mathrm{~W}$ grupie wiekowej $46-55$ lat 48,81\% ankietowanych zadeklarowało swój poziom wiedzy na temat budżetu partycypacyjnego jako znikomy lub mały, a 20,24\% jako duży lub bardzo duży.

${ }^{25}$ Ze szczegółami projektów zapoznało się 38,1\% respondentów z grupy wiekowej 36-45 lat oraz $36,99 \%$ z grupy wiekowej $46-55$ lat.

${ }^{26}$ Realizację projektu monitorowało $37,21 \%$ respondentów z grupy wiekowej 36-45 lat oraz 25\% z grupy wiekowej 46-55 lat.

${ }^{27}$ Chęć udziału w kolejnych edycjach RBO zadeklarowało 72,17\% badanych z grupy wiekowej 36-45 lat oraz 67,59\% ankietowanych z grupy wiekowej 46-55 lat. 
[10] Wampler B., Participatory Budgeting in Brazil. Contestation, Cooperation, and Accountability, The Pennsylvania State University Press, University Park, Pennsylvania 2007.

\title{
PARTICIPATING BUDGET - KNOWLEDGE AND ACTIVITY OF GENERATION X
}

\begin{abstract}
The participatory budget is a tool of local government budget management used in the world for almost thirty years. Its application gives local community members the opportunity to decide how to distribute all or part of public funds. It affects, inter alia, the increase in the activity of citizens, the breaking of the barriers between the authorities and the inhabitants, the realization of important projects for local communities. The positive effects of using this idea by the self-governments of South American cities have become an impetus for its application by self-governments on all continents. Polish municipalities have also used it in practice since 2011. Since then, the number of Polish self-governments has increased from year to year. You can even say that in Poland there appeared something like "fashion" on the participation budget.

The article presents the results of questionnaire surveys on the level of knowledge of issues related to participatory budgeting by the representatives of generation $\mathrm{X}$ who are residents of Rzeszów and their activity in this field. An introduction to the assessment of the knowledge of the idea of a participatory budget was presented. In the following, the residents' participation in the participatory budget was assessed and the factors influencing this activity were analyzed.
\end{abstract}

Keywords: participatory budgeting, participatory democracy, social opinions, generation $\mathrm{X}$

DOI: $10.7862 / \mathrm{rz} .2017 . \mathrm{mmr} .45$

Tekst złożono w redakcji: listopad $2017 \mathrm{r}$.

Przyjęto do druku: styczeń 2018 r. 